\title{
Recordações de como me deparei com e tentei compreender o espaço por meio de uma sociologia
}

Roberto DaMatta

Tal qual o tempo, o espaço gera o esquecimento; fá-lo, porém, desligando a pessoa humana das suas contingências e pondo-a num estado livre, primitivo; chega até mesmo a transformar, num só golpe, um pedante ou um burguesote numa espécie de vagabundo. Dizem que o tempo é como o rio Lete ${ }^{I}$; mas também o ar de paragens longínquas representa uma porção semelhante, e o seu efeito, posto que menos radical, não deixa de ser mais rápido.

1. O rio do esquecimento $\mathrm{e}$ da mortalidade, na topografia mitológica greco-romana.

O convite da professora Fraya Frehse para que eu abordasse, neste Dossiê, "as ciências sociais e o espaço" com base em minha própria trajetória de pesquisa é bem-vindo porque me proporciona a oportunidade de relembrar - com o direito que as décadas de investigação, de dúvidas, de desânimos, de certeza de uma enorme ignorância e de estudo conduzem - essas reflexôes sobre o "espaço" como uma "categoria social" tal como elas surgiram no meu trabalho.

Comecemos do começo. E eu tenho pelo menos três começos.

O primeiro surgiu no outono de 1963, quando vivi a minha primeira experiência fora do Brasil e, no hemisfério norte, sofria o múltiplo choque de um frio desconhecido, do igualitarismo do American way of life, do ensino de Harvard, e cursava - inseguríssimo - um seminário de dois semestres, famoso, porque obrigatório a todos os alunos da pós-graduação, intitulado "Social Relations 205: introduction to social anthropology". Esse seminário era ministrado por três instrutores: dois professores titulares, Douglas Oliver 
2. Faço uma diferença fundamental entre "ler" e "estudar" um autor que reconhecemos como mestre. Ler é assimilar ideias; estudar é ler anotando, aplicando e, sobretudo, dialogando - muitas vezes contra - o autor. Até hoje tenho essas notas de leitura feitas entre 1963 e 1964, quando, em setembro, retornei ao Museu $\mathrm{Na}$ cional e ao Brasil.

3. Elaborei tal ponto em Relativizando: uma introduçāo à antropologia social (cf. DaMatta, 1981). Numa digressão sobre o que chamei de "fábula das três raças", sugiro que nosso racismo é uma combinaçẫo de hierarquia e igualitarismo. Um igualitarismo que, no entanto, raramente élevado às últimas consequências na sociedade, como ocorre sistematicamente no campo criminal e nisso que insistimos em chamar de "política". Branco, índio e negro, como supostas "raças" que, misturando-se, deram origem ao "povo brasileiro", formam um triângulo no qual cada categoria tem o seu lugar, além dos triângulos intermediários de mestiços, que, no caso brasileiro, têm legitimidade cultural ou ideológica. Nesse trabalho denuncio o evolucionismo vitoriano que faz parte das concepçōes mais difundidas sobre a natureza da sociedade e de sua evolução no Brasil, como aquela de que o Brasil é um país na sua infância e outras estultices do mesmo calibre. Ali, e em outro lugar, quando falo das noçōes básicas de "tradição" no Brasil (cf. DaMatta, 1993, cap. 5), denuncio esse marxismo toldado de catecismo positivista vitoriano e evolucionista que deixa para o Estado todas as tarefas e, assim, isenta a sociedade de qualquer movimento para a mudança dos seus padrōes de conduta. (especialista na Polinésia, cujo viés era socioantropológico) e John Whiting (dedicado fundador de uma "antropologia psicológica”, a partir de Abraham Kardiner e Ralph Linton, cuja orientação era boasiana e culturológica); e um professor assistente, mas com a credencial de ter criticado e recebido uma rara resposta de Claude Lévi-Strauss: David Maybury-Lewis (ex-aluno de Rodney Needham em Oxford, durkheimiano, mas cético em relação a teorias). Estão hoje todos mortos, mas vivem no firmamento do meu espírito.

Foi nesse seminário que fui obrigado a estudar ${ }^{2}$ - em particular Durkheim e seus discípulos: Henry Hubert, Celestin Bouglé, Robert Hertz e sobretudo Marcel Mauss. Tomei assim pela primeira vez o mestre como um pensador crítico, como um fundador, ao lado de Max Weber, da sociologia como uma investigação comparativa sobre os modos de conceber as relações humanas, cujo ponto de partida era a noção segundo a qual todo sistema formava uma cosmologia, com uma sensibilidade original para as diferenças entre esses sistemas. É um viés comparativo que ficou na base da sociologia comparada que em alguns lugares se transformou em antropologia social. No Brasil, eu não havia lido Durkheim e dele ouvira falar apenas como pedagogo e sociólogo de direita, num péssimo curso de didática que culminou minha vida estudantil na Faculdade Fluminense de Filosofia, em Niterói, no final de 1950 .

Foi, pois, numa fria madrugada de Cambridge, Massachusetts, que li, no mês de setembro de 1963, As formas elementares da vida religiosa e, deslumbrado, logo percebi como certas passagens remetiam a Karl Marx, que, tal como fazia Durkheim, embebia (e dissolvia) a subjetividade, concebida como uma agência exclusivamente individual, no conjunto de relações sociais às quais ela pertencia e que, de fato, a construíam. Relativizava assim a ideia de uma natureza humana universal, que, no meu caso - vejo isso perfeitamente bem, agora que sou velho -, estava relacionada com o velho catolicismo romano hierarquizado, cheio de almas penadas e carregado de culpa, bem como ao positivismo marxista e evolucionista que havia aprendido no Brasil - esse país tão afeito a catecismos ${ }^{3}$.

Nesse livro de Durkheim, descobri como tanto o empiricismo utilitarista, prático e sensorial, quanto o idealismo iluminado, que postulava ideias inatas ou leis da história, tinham como filtros ou mediadores uma entidade viva chamada "sociedade". Sociedade que não era um mero substantivo, mas um modo especial e dinâmico de constituir consciências e totalidades, posto que ela possuía seu próprio plano e realidade e, como tal, impunha-se aos seus criadores, coagindo-os imperativamente de modo aberto ou oculto, de tal 
maneira que dela não se escapava com facilidade. A menos - é claro - que pudessem percebê-la em todas as suas consequências - vale dizer: em todo o seu poder de iludir, de obrigar a seguir padróes e moralidades, de ser o centro da vida e do mundo e de ter, tal como ocorre com os fetiches, o poder de internalizar em seus membros a impressão de que tudo o que fazem é o melhor, é o mais normal e, mais que isso, é natural. Naquele instante vislumbrei que fazer sociologia seria mais do que investigar um tema, grupo ou questão. Seria, acima de tudo, elaborar uma teoria do conhecimento ${ }^{4}$.

Vale a pena citar o texto que naquela noite iluminou meu espírito, marcando intensamente meu aprendizado sociológico, ao mesmo tempo em que me conscientizava do "espaço" como um tema básico na investigação sociológica:

$\mathrm{Na}$ raiz dos nossos julgamentos, há um certo número de noções essenciais que dominam toda a nossa vida intelectual; são aquelas que os filósofos desde Aristóteles chamam de categorias de entendimento: noçôes de tempo, de espaço, de gênero, de número, de causa, de substância, de personalidade etc. Elas correspondem às propriedades mais universais das coisas. São como uma sólida moldura que encerra o nosso pensamento; este não parece poder libertar-se delas sem se destruir, pois tudo indica que não podemos pensar objetos que não estejam no tempo ou no espaço, que não sejam quantificáveis etc. As outras noções são contingenciais e instáveis; podemos conceber que possam faltar a um homem, a uma sociedade, a uma época, enquanto aquelas nos parecem quase inseparáveis do funcionamento normal do intelecto. Elas são como que a ossatura da inteligência (Durkheim, [1912]* 1996, pp. xv-xvi).

Décadas depois, lendo Schopenhauer - um autor que me foi apresentado por Irving Yalon e Thomas Mann -, não pude deixar de ficar intrigado com o fato de que o conceito-chave para a sociologia de Durkheim é o de "representação" - o mesmo conceito que surge com Kant e dá título à obra culminante de Arthur Schopenhauer, O mundo como vontade e representação (grifo meu), publicada em 1819. Com a diferença, reitero, de que, se Kant (e, sem dúvida, Hegel) é o ponto de partida, Durkheim desvia-se no sentido de postular a "sociedade" como idêntica aos sistemas sociais mais "elementares" (como as tribos australianas e da América do Norte, àquela época chamadas de "primitivas" ou "selvagens"), exemplares legítimos do uso dessas categorias, que, não obstante sua postulada universalidade (e essa é a diferença da Escola Sociológica Francesa), ajudam a alicerçar múltiplos
4. No texto citado elaboro essa teoria do conhecimento proposta por Durkheim ao sugerir que deve haver uma conexão insuspeitada entre o direito romano, o positivismo comteano e o marxismo evolucionista, adotados pelas nossas elites como ideologias políticas, e a velha hierarquia ibérica (e aristocrática) como valor. Isso embora o componente hierárquico seja atravessado por um ideal igualitário presente na cultura que se modernizava, e que em seguida foi oficializado pela república. A valorização do todo (lido apenas como o Estado) sobre a parte (o cidadão-indivíduo que integra a sociedade) sempre teve precedência no caso do Brasil estudado pelos brasileiros. Daí a popularidade das ideias fora do lugar e de um país onde a história não se desenrolava de acordo com as etapas encontradas nos países tidos como "normais" e "modelares". Erro hoje difícil de manter diante do fato de que não há mais países exemplares. O Primeiro Mundo virou outro Terceiro Mundo.

*A data entre colchetes refere-se à edição original da obra. Ela é indicada na primeira vez que a obra é citada. Nas demais, indica-se somente a edição utilizada pelo autor (N. E.).

novembro 2013 
5. Tal diferença é absolutamente fundamental. Basta ler os intérpretes clássicos mais arcaicos do Brasil para constatar que em seus escritos não havia ideia de sociedade, mas de conglomerados degenerados. Coletividades de mestiços com instintos, taras de origem (como diz Azevedo Amaral) e atavismos dos quais era impossível escapar. Como se isso não fosse suficiente, havia ainda, contra o Brasil, o clima (os "tristes trópicos"), a geologia, o litoral, o regime dos rios e a genética. Éramos, sem dúvida, não apenas um país com ideias fora do lugar, mas com uma coletividade ela própria fora das leis da história, e que, para esses autores, não tinha o menor peso. A descoberta dos costumes, seja como prática ou como ritual, é, penso, uma das contribuiçōes da minha antropologia. universos. Mundos (ou luas, como disse certa vez Mauss) a serem compreendidos em seus próprios termos, e não através de um sistema filosófico eurocentrado.

Intriga-me, acima de tudo, o entendimento do conceito de representação tanto pelo filósofo alemão, básico na fundação da modernidade e do anti-hegelianismo, quanto pelo francês, que inventou um modo de investigar as coletividades humanas não como raças, aglomerados de indivíduos em conflito e limitados pelo clima e pela geografia; não como povos escolhidos: judeus, muçulmanos, cristãos, pagãos ou malditos; não como classes pobres ou exploradas, em plena luta por sobrevivência; não como países poderosos ou nações destinadas à subserviência e ao imperialismo; mas como sistemas de classificação: como engenhos capazes de reinventar suas próprias experiências e histórias por meio de "re(a)presentaçôes". Ou, como diz Schopenhauer, antecipando Clifford Geertz em algumas dezenas de décadas: "os conceitos podem ser denominados de maneira bastante apropriada representações de representaçôes" (Schopenhauer, [1819] 2005, p. 87, grifos meus). Ou seja, através de categorias ancoradas em linguagens ou códigos não biológicos mais ou menos precisos, sempre em mudança e redefinição, e - eis o que perturba - decididamente arbitrários. Essa filha da liberdade que faz com que as diferenças entre línguas e culturas humanas sejam cabalmente inexplicáveis pela geografia, pelo clima ou pela biologia ${ }^{5}$.

Hoje eu tenho para mim que a Escola Sociológica Francesa que termina em Claude Lévi-Strauss e Louis Dumont - aquele, o Copérnico do estudo das sociedades tribais, e este, um decisivo pensador crítico do individualismo dominante - tem o mesmo papel fundador e transformador do romance na consolidação intelectual, psicológica e democrática da modernidade, pois quando Durkheim e Mauss tomam a sociedade como um objeto, vendo-a em suas propriedades, eles a liberam dos seus membros. Eles ampliam as asas das nossas atormentadas subjetividades e dos nossos espaços interiores, revelando que os nossos limites ou suficiências têm como fonte não apenas a moralidade religiosa, política ou, como queria Weber, burocrática, mas cada vez mais o nosso bom senso. $\mathrm{Ou}$ - quem sabe? - um planeta em processo de extinção, o que representa num plano concreto um retorno à totalidade, esse fantasma que o hiperindividualismo fundado no triunfo da ideologia econômica (a expressão é de Dumont) tentou assassinar, quando promoveu a subjetividade individualista a algo racional, centrado, indivisível e infenso a irracionalidades e conflitos. Algo que Schopenhauer criticou e, na sua esteira, Nietzsche elaborou e Freud concretizou, com suas reiteradas demonstrações 
do poder devastador (para o bem e para o mal) da vontade humana - o desejo insaciável e (des)constitutivo que, ao lado da racionalidade, também faz parte do nosso modo de ser.

Meu segundo começo com a questáo do espaço (ou do espaço como questão) foi menos cosmológico e pomposo.

Ele aconteceu quando, nos idos de 1962 e numa aldeia perdida no sertão goiano, solicitei a um informante Apinayé um diagrama da aldeia em que estávamos, indicando a casa onde ocorria a entrevista. Conforme tento elaborar no meu livro sobre esse grupo (cf. DaMatta, 1976, p. 62), a aldeia tinha um desenho retangular que eu havia medido com o máximo de precisão que os meios de que dispunha permitiam (uma desbotada fita métrica, minhas próprias pernas e um auxiliar de pesquisa analfabeto), mas o informante a desenhava (ou a representava) como um círculo!

Após os primeiros esboços, deixei que assim o fizesse e somente depois pedi para que fosse assinalada a casa onde acontecia o nosso encontro (uma garagem ao lado da morada do encarregado do Posto Indígena). Em segui$\mathrm{da}$, verificando que o informante não hesitava, pedi que fossem marcadas todas as outras casas da aldeia, o que foi feito de acordo com o círculo desenhado. Tal desenho - que convertia um retângulo num círculo - foi reproduzido no meu livro, e o meu choque com esse modo divergente de enxergar o "espaço real" revelava certamente o mesmo impacto que temos quando olhamos um desenho de um expressionista ou de um Picasso na sua fase cubista. Pois, se eu via a realidade "fotográfica" e "realmente" como uma figura quadrangular, o meu informante a via como um círculo que, como sabem todos os estudantes dos grupos de língua Jê, era a forma pela qual esse pedaço do real que distinguimos como "espaço" ou "topografia" é configurado e enclausurado naquela humanidade.

De fato, a humanidade Apinayé não se concebia estabelecida num local linear ou em xadrez, como é o caso da nossa tradição, mas se enxergava vivendo num universo circular, talvez numa esfera, pois há a abóbada celeste e um mundo subterrâneo, e ambos se encontram nos extremos do círculo que delimita o mundo. Nas fronteiras dessa tangente horizontal onde vivemos, seres míticos tentam em vão derrubar o enorme arco da abóbada celeste a golpes de machado. Ademais, é no poente o lugar da enorme aldeia dos mortos; e no nascente ocorre a renovação da vida. Rituais de nominação (que fazem as 
6. Durkheim tem uma brilhante consciência da totalidade (e do coletivo) e do seu poder explícito ou implícito de coagir, o que é extraordinário no país que inventou o voluntarismo da revoluçāo. Freud, por sua vez, tem uma brilhante consciência do sofrimento neurótico que pesa sobre os indivíduos de modo explícito (como sintomas) ou implícito (como seres contraditórios). Não tenho nem força nem tutano intelectual para levar à frente a comparação entre dois intelectuais europeus que, cada qual a seu modo, libertaram o sujeito individual de algumas de suas amarras. pessoas nascerem de novo, agora como uma persona social de pleno direito) são realizados com os nominados voltados para o nascente, ao amanhecer.

Como era possível entender isso sem passar pelo choque de ver o desenho nativo como uma "de-formação", conforme faziam os meus nobres ancestrais evolucionistas, utilitaristas e indigenistas, todos aprisionados por uma visão de mundo empiricista e utilitária, baseada no universalismo, no evolucionismo crasso do período vitoriano, na primazia dos sentidos e da realidade absoluta e uniforme do real e da natureza humana que obedeceria às chamadas "leis da história"? E como não perceber o rigor da lição durkheimiana, segundo a qual a sociedade era um formidável engenho de ver-se a si mesmo, e que se impingia aos seus membros e a tudo o mais que a cercava, inventando inclusive a natureza, pois sem cultura não há natureza? Se os homens conhecem limites quando perecem, a sociedade os ignora e vai além deles, dando-lhes a esperança da divindade, da perfeição e da imortalidade. Era ela que permitia, por meio da "religião", ver o universo como uma totalidade indo além dos espaços que necessariamente demarcavam a vida cotidiana, e mesmo assim com suas inflexões particulares, próprias de cada sistema. Essa é - aprendi com Durkheim e sua escola - a visão idealizada pela vida religiosa e pelas ideologias políticas, que hoje fazem o papel daquela.

Para muitos, a visão de Durkheim aprisionava a vida social numa "mentalidade coletiva" incompatível com o individualismo dominante, valor da vida social euro-americana. Para mim, porém, essa descoberta foi uma liberação. Graças ao desvendamento do peso, da sedução e da sutileza com a qual a sociedade se impigia a todos nós, tínhamos por fim a chave para uma liberdade calculada e menos ingênua do que a tal "liberdade" que fazia parte das ideologias da mudança que - e o caso do Brasil me parece exemplar - sempre repetiam o passado como farsa, e talvez como um castigo, trazendo de volta práticas políticas e sociais que pretendiam abolir. Porque a paisagem social, tal como a mental, conforme ensinou Freud na mesma época, não pode ser apagada. Ela sempre retorna como pesadelo ou dilema ${ }^{6}$.

A aldeia circular que estava na cabeça dos meus informantes-professores Apinayé foi o meu primeiro contato com a força e com a persistência das ideologias, e com a relatividade do espaço. Era uma prova de que a "cultura" existia de verdade. Ela me mostrava que os valores do sistema manifestavam-se em tudo, começando, como ocorre conosco, na forma de suas aldeias e moradias. 
Meu terceiro momento de começar a lidar com o espaço foi quando decidi interpretar o Brasil como sociedade, farto que estava de ler e estudar tantas interpretaçóes do Brasil apenas como Estado ou "nação" (como uma comunidade política vivendo um drama no qual atores individuais e classes sociais estavam em conflito), e jamais como sociedade e cultura: como um estilo rotineiro de vida. De fato, do meu ponto de vista, muitos dos problemas nacionais brasileiros tinham sem dúvida a ver com a economia e com a política, mas o Brasil poderia ser interpretado também como um sistema de valores ou um fato social total, sob pena de ficarmos reduzidos somente ao plano de um conflito político voluntarístico, como - aliás ainda ocorre até hoje.

No meu entender, as coletividades modernas tinham duas dimensões muito claras. Havia um coletivo espacializado ou territorializado, dotado de soberania, pois ele se denominava dono de um pedaço de terra, onde suas regras não poderiam ser nem contestadas nem relativizadas, e que era administrado conscientemente por meio de leis e decretos escritos. Aprendi essa visão lendo o maravilhoso ensaio de Mauss, La nacion (de 1920 e ignorado pelos politicólogos), e a obra de Dumont, na qual se mostra como as nossas coletividades são quase sempre autorreferidas e não interdependentes: são coletivos individualizados ou individualistas. Ou seja, tudo isso que chamamos de "nação" tem a ver com o lado consciente e escrito da vida coletiva, inclusive com o Estado. No plano do grupo como nação, temos o pressuposto de indivisibilidade, que é uma cópia do indivíduo-cidadão moderno. A homogeneidade que persegue a Europa e os Estados Unidos até hoje resulta desse postulado de que a nação deve ser uma coletividade idêntica a si mesma: falando a mesma língua, tendo um padrão monetário exclusivo de troca, marcada por uma mesma "raça", professando uma mesma religião, vivendo num mesmo território e sendo fiel a um mesmo conjunto de leis ${ }^{7}$.

Mas ao lado dessa coletividade há outra, diversa ou até mesmo divergente, que se chama "sociedade" ou "cultura”. Se a nação é feita por território, moeda, Estado, cidadania, bandeira e constituiçôes exclusivas, a sociedade toma consciência de si mesma por meio de uma língua, de valores, castas, famílias, casas e práticas sociais, que vão desde a experiência pública rotineira no mundo moderno (historicamente marcada) até certas singularidades que o próprio grupo acredita serem exclusivas e regionalizadas, como a comida, as festas religiosas, a paisagem, o carnaval, a preguiça, o jeitinho, a saudade, a hospitalidade e a música. A nação tem uma história e uma fundação; ela é obcecada com a unidade, a universalidade e a
7. Essa ênfase no homogêneo, além do preconceito que é postulado como parte de toda identidade, engendra - em alguns casos - a segregaçăo. Trata-se de uma forma institucionalizada e, mais que isso, territorializada de preconceito. Ela obriga a separar o impuro ou heterogêneo do puro ou homogêneo. No caso brasileiro, vale notar que, se adotamos as teorias racistas, a mestiçagem em alta escala impediu a sua prática. Aliás, no nosso caso, a teoria do "branqueamento" legitimava exatamente aquilo que os racistas clássicos, europeus e americanos, mais temiam e abominavam: a intimidade fisica e sexual entre seres de raças diferentes $\mathrm{e}$ opostas, quando produziam um mestiço ou um híbrido. Nosso racismo favorece o hibridismo; o anglo-europeu o estigmatiza porque condena a intimidade entre grupos social e fisicamente diferenciados. Nesse caso, há o pressuposto implícito de que uma comunidade de iguais em direitos deve também ser igual em todas as esferas da vida. 
8. Observo, repetindo o que disse em vários momentos de minha obra, que a nação (e o país) tem um mapa, ao passo que a sociedade e a cultura, não. Estas podem ter regiōes, mas é muito difícil, se não impossível, demarcá-las num espaço preciso: há, nos Estados Unidos e nos continentes, pedaços vivos da sociedade brasileira. A sociedade ou a cultura têm uma profundidade e uma temporalidade não mapeadas: sem início e fim, conforme se vê no seu folclore musical e narrativo, nos gestos, nas técnicas de corpo, nas danças e comidas. Desse modo, uma pessoa pode pertencer à nação pelo território, mas não ser membro da sociedade (caso dos chamados índios brasileiros); e pode pertencer à sociedade, mas não à nação, como ocorria com os nossos escravos. homegeneidade. A sociedade, porém, tem mitos e possui uma tolerância para a divergência e a impureza - no caso do Brasil, o famoso mulatismo cultural e social, que quase sempre ofende os que tomam o estudo de um país apenas como Estado nacional, deixando de lado ou vendo como inferiores as suas manifestações culturais ${ }^{8}$.

A nação sofre de história, frequentemente - como tem sido o nosso caso de uma história errada, feita por ausências e eventos fora de hora e de espaço. Ademais, a nação pode ser medida, quantificada e posta em confronto com outras nações, em escalas que vão do mais "adiantado" ao mais "atrasado". Já a cultura não pode ser reduzida a nenhuma escala. Como aprendemos com o romantismo alemão e sua transposição ao culturalismo antropológico sobretudo de Franz Boas e de Robert Lowie, não teria sentido situar numa escala a poesia de Goethe, Whitman e Gonçalves Dias! Nem a novelística de Dumas, de Machado de Assis e de Hemingway. As economias nacionais podem ser graduadas e mensuradas, mas o uso da moeda em festas ou na poupança (no seu abuso ou não uso) não pode ser escalonado num eixo absoluto. A passagem da nação para a sociedade ou, melhor ainda, o diálogo entre uma e outra - ler a história como um mito e o mito como uma má história - é algo claro na vida dos povos que até meio minuto atrás eram chamados de "países do Terceiro Mundo" ou de "países subdesenvolvidos".

Foi precisamente quando tentei transpor as teorias antropológicas do ritual de Victor Turner, Arnold Van Gennep, Robertson Smith e Edmund Leach, vigentes ou emergentes no amanhecer da década de 1970, para o estudo do carnaval brasileiro, que me deparei, conforme explicito sobretudo em meu livro Carnavais, malandros e heróis: para uma sociologia do dilema brasileiro (cf. DaMatta, 1979), com o espaço, o tempo, o número e o gênero como uma questão (ou um objeto sociológico), dentro dos quadros dos estudos do Brasil pelos brasileiros. Pois nos rituais, conforme sabemos, o tempo alonga-se ou acelera-se; e o espaço sofre as deformaçôes típicas dos desenhos dos Apinayé. Logo descobri que o carnaval não poderia ocorrer no espaço da moradia, porque o lar - como na Roma antiga que li em Fustel de Coulanges - é sagrado. Havia, como afirmo no livro supracitado, um "carnaval de rua" e outro mais fechado, "de clube". Não são múltiplos carnavais, um para cada classe social - como dizem meus críticos mais ingênuos -, mas muitos carnavais que se realizam simultaneamente nesses espaços segmentados, redesenhados ou "fantasiados" para cada um deles. No carnaval oficial, ancorado no Rio de Janeiro do governo Brizola - sob a égide de um antropólogo de renome e talento indiscutíveis, 
Darcy Ribeiro -, num espaço especializado e individualizado chamado de "sambódromo", a mobilidade que convertia todos os espaços em "ruas", transformando até mesmo o recinto sagrado das igrejas - conforme diz Mikhail Bakthin (1987) no seu clássico A cultura popular na Idade Média e no Renascimento -, foi liquidada. O carnaval centrou-se, deixando de ser uma festa aberta e, como digo, sem foco ou centro. Uma celebração que comemorava a própria vida no que ela tem de grotesco, de contraditório e de surpreendente. Por isso, as pessoas podem sair dos seus papéis usuais e "brincar" de ser outras coisas. O mesmo ocorre com os espaços, igualmente "vestidos" (ou fantasiados) para a festa. O direito ao carnaval, no Brasil, tem sido mais observado do que o de cobrar de volta os impostos que pagamos aos nossos administradores públicos incompetentes e corruptos. Se, conforme argui uma vez, o carnaval fosse proibido, ocorreria uma revolta entre nós?.

Mas, para além dos ritos carnavalescos, há também, no Brasil, rituais cívicos e religiosos, a saber, a Semana da Pátria e a Semana Santa.

Em alguns ensaios, refiro-me a esses momentos, nos quais o espaço rotineiro é suspenso, como um "triângulo ritual". Ao fazer isso, chamava a atenção para a noção implícita de simetria ou de direito de lugar (ou de espaço) que cada coisa e pessoa deve ter neste nosso universo, que, conforme descobri - com ajuda do Alexis de Tocqueville de Democracia na América, um autor conspicuamente ausente das interpretações clássicas do Brasil (confira Freyre, Prado Jr., Buarque de Holanda e outros) -, era um sistema também hierarquizado. Um mundo no qual, como dizia o doutor Teodoro Madureira, o primeiro marido de dona Flor do imortal - e destronado por alguma crítica - Jorge Amado, "um lugar para cada coisa e cada coisa em seu lugar!". E mais: é um lugar com pelo menos três "leituras simbólicas" simultâneas, legítimas e paralelas. Lido pela perspectiva do espaço carnavalesco, tudo era possível, porque o espaço orgiástico do carnaval tendia a promover o oculto (e o obsceno), no lugar do manifesto e do oficial. Mas, visto pelas formalidades cívicas nas quais se dramatizam (roubei a expressão de Victor Turner) a ordem e as hierarquias, celebravam-se o legal e o legítimo. Nas formalidades cívicas, superiores e inferiores são vistos nos seus devidos lugares. Reitera-se a crença na dimensão política da vida social, de modo que quem manda ou é superior ganha destaque e é aplaudido ou vaiado na cerimônia. Já nos festivais religiosos, combinam-se essas dimensões. Uma de suas características mais patentes é a conjunção do sagrado - geralmente por meio de uma virgem-mãe, como Nossa Se-
9. O carnaval é um direito dado pelo costume e, portanto, pela sociedade, que, em tempos modernos, foi administrado (e amestrado) pelo Estado. Todos têm direito a um carnaval que é brincado ou pulado individual ou coletivamente - em bloco ou cordão. Foi por isso que sugeri, em Carnavais, malandros e heróise em outros ensaios, que o carnaval tendia para o lado individual sem, entretanto, romper com o coletivo. A competição ocorria mais no carnaval do que nos outros festivais que eram hierarquizados.

novembro 2013 
nhora Aparecida (uma virgem negra) ou de Nazaré (ambas achadas por pobres) - com o universo dos símbolos oficiais, como a bandeira nacional ou estadual, que são desse modo sacralizados. No fundo, até o espaço do carnaval tem sua quota de sagrado nos chamados "destaques" dos desfiles das escolas de samba; do mesmo modo que uma procissão tem sua dimensão profana, com uma periferia feita de vendedores ambulantes e de espectadores que ali estão para tirar proveito da festa, que implica em feriado.

O ponto focal foi, para mim, a descoberta desses três modos de celebração, os quais faziam plena justiça a uma lógica do mais ou menos, ou da ideia antiga - pois dela já falava Francisco de Sá de Miranda, um poeta português do século XV, quando dizia que "Pouco por força podemos/ isso que é, por saber veio/ todo mal jaz nos extremos/ o bem todo jaz no meio". Como não ter o mediador, ou o mais ou menos, ou o eterno adiar que mulatiza o tempo, o gênero e o espaço como uma dimensão social significativa, num sistema onde o legal se confunde com o pessoal, do mesmo modo que o carnaval, como uma festa do "vale tudo", é paradoxalmente legalizado? Sergio Buarque de Holanda, de quem tirei a citação do poeta, fala disso em outro contexto, em Raízes do Brasil.

Somos um país com muitos feriados, e outros mais ainda serão certamente inventados, porque o nosso universo social é constituído por pelo menos três modos de ler ou enxergar a nós mesmos: de ponta-cabeça, de cabeça para cima e pelas lentes do outro mundo, que engloba, nos seus três espaços - céu, inferno e purgatório -, essas tríades nacionais.

Émile Durkheim, que me ensinou a distinção essencial entre sagrado e profano, usava o espaço como base para essa oposição. Terminemos falando como a utilizei em meus livros.

O sagrado é o que fica num espaço removido, guardado e infenso às invasões do cotidiano e do trabalho obrigatório, que, em geral - com perdão dos calvinistas e, conforme estão descobrindo os americanos pós-modernos -, é um castigo. As gavetas, as urnas, as covas, as cavernas, as caixinhas de joias, os orifícios do corpo humano e as vitrines são repositórios típicos e removidos da vida diária: repositórios do sagrado. O profano não é tão somente o banal e o comum, mas é o repetitivo em escala curta e insignificante: o rotineiro que trivializa mas, ao mesmo tempo, segura o mundo, pois é a rotina que garante a plausibilidade da vida em sociedade. É essa vida sem instintos, sem programas fixos, essa existência atravessada pela contradição entre os papéis e escolhas que mudam rumos e pela tragédia que muitas vezes põe à prova ou nega, afirmando, a humanidade do humano. 
Pois que não temos miolo e, sem miolo ou programação, inventamos um lugar removido do mundo, onde nada muda ao sabor das circunstâncias. Nada é mais complexo do que o eterno, que é o espaço sem começo, meio e fim. O local da indistinção absoluta. Espaço impossível de ser pensado para todos nós, criaturas finitas e necessitadas de rituais e de seus coadjuvantes: música, fantasia, cenário, sensualidade, beleza, harmonia, bebidas e comidas especiais, mais bebida do que comida, e, para além disso, de um tempo sem indiferença: um tempo e um espaço concretos - com início, meio e fim; um espaço com três paredes e uma plateia. Um espaço especial e um tempo mais lento e solene, diferenciado, porque só os inferiores, os comuns e os servidores - os que andam depressa - estão no tempo acelerado do servir; nós, os nobres e puros a serem devidamente servidos, andamos no compasso da solenidade que é o tempo adequado ao espaço do templo, do altar, do palco, das coberturas e do poder. Exceto, é claro, na loucura do frenesi carnavalesco.

Uma nota final para um assunto sem fim.

Quando descobri a oposição entre sagrado e profano, e a da casa, da rua e do outro mundo no caso brasileiro, imediatamente vi que essas oposições não eram mutuamente exclusivas. Desse modo, e como notou Durkheim, há um profano no sagrado. Lembro que ele dizia no livro As regras do método sociológico que, no paraíso, os pecados leves seriam graves ofensas. Pela mesma lógica, há sagrado no mais intenso profano. Que as nossas sexualidades falem disso, pois reiteramos o encontro físico (que tem fim) transformando-o no amor, que seria infinito até mesmo, como dizia Vinicius de Moraes no "Soneto da fidelidade", enquanto possa durar...

Assim, eu me dei conta de que há casa e rua, e rua na casa (varanda, sala de visita e quintal); como há casa na rua (jardins, esquinas, praias onde certos pedaços são apropriados por usuários, não sendo, entretanto, de ninguém). Estamos tratando aqui de dualismos complementares e relativizáveis, formados por contrastes que são interdependentes e hierárquicos. Assim como ocorre com a casa e a rua, ocorre também com o bem e o mal, que se opõem num nível mas não podem existir um sem o outro, como é o caso da vida e da morte, do masculino e do feminino, do velho ao relativamente jovem, do pai ao filho, do soldado ao oficial, do plebeu ao aristocrata e do escravo ao senhor. Seus contrastes não formam dualismos absolutos e finais, 
como imagina o fundamentalismo moderno, que só sabe pensar um espaço final, geométrico e platônico - porque perfeito, no qual tudo se dissolveria e o bem englobaria definitivamente o mal e a vida eterna, a morte.

Tal modo de ver as oposiçóes nos leva a perceber com clareza outro fenômeno, que se liga ao englobamento desses contrastes, pois, conforme sabemos, muitas vezes o mundo é englobado pelos inferiores, pela mulher, pela música, pela sensualidade, e temos um espaço e um tempo carnavalesco. Mas, se o contrário acontece, há uma formalidade.

Um dos maiores problemas no estudo dos dualismos foi, conforme demonstra Dumont (1968), a ideia ocidental de que um dos termos do contraste seria perpetuamente englobador quando, de fato, há um elo complexo entre os elementos postos em contraste. São "oposições segmentares", como sugere Dumont na sua releitura de Evans-Pritchard - numa introdução capital à tradução francesa do livro sobre os Nuer (cf. Dumont, 1968). Essas oposições são reais num nível, mas cancelam-se ou acendem-se em outro. Eis aí, no dizer de Dumont, um novo estruturalismo. Estruturalismo sociológico e básico na formação das identidades (e dos etnocentrismos), que consiste em opor irmão mais velho e mais novo em casa, mas em religá-los como "irmãos" diante dos "primos"; para, em outros espaços, juntar "irmãos e primos" quando há um confronto com outra casa e família. Somente para nos reunirmos de novo como membros de um bairro, tribo ou cidade quando irmãos, primos e vizinhos se confrontam; desta vez, porém, com pessoas de outras tribos, bairros ou cidades. E assim vamos ampliando ou diminuindo os espaços e os tempos, de acordo com o papel ou a identidade que estão em jogo.

Seria uma tolice pensar que as identidades são fixas e dadas de uma vez por todas. Mas seria uma fantasia imaginar que elas não existem e não são essenciais, como parâmetros críticos da vida social. Para provar isso, as reversões hierárquicas estão sempre presentes e se intrometem no mundo aparentemente ordenado que tentamos construir para viver. Foi com essa visão mais flexível e mais dialética da vida social que estudei o espaço da casa, da rua e do outro mundo no Brasil. Como Gilberto Freyre, eu tinha a noção do contraste geográfico ou ecológico e físico, mas, conforme disse explicitamente no prefácio do meu livro $A$ casa \& a rua (cf. DaMatta, 1985) - resenhado pelo próprio Gilberto com certo grau de censura nas páginas de $O$ Estado de S. Paulo, pois ele insinua um plágio -, vou além do mero espaço geométrico e apanho o contraste como revelador de uma cosmologia. De uma visão axial da vida nacional por nós, brasileiros, que, penso eu, até mesmo no outro mundo acreditamos ter uma casa e uma rua. 
Outro elemento importante é afirmar, como fiz nesse mesmo texto, que as interpretaçōes do Brasil feitas por sociólogos, economistas e politicólogos tomam como base o mundo público e da rua; ao passo que os antropólogos e sócio-historiadores estudam o Brasil privilegiando a casa e o mundo diário, de modo muito mais pessoal, tangível e obviamente discutível quando comparado a uma plataforma avaliativa exclusivamente empirista. Não seria apenas o caso de se ser de direita ou de esquerda, mas algo muito mais complexo e culturalmente interessante. O espaço inicial ou básico do estudo determina ou coage o estudioso a caminhar dentro de uma dada linha, levando-o a definir ou compreender o Brasil como sociedade ou nação; como conjunto de hábitos ou como sistemas jurídicos, políticos ou econômicos. Visto como dimensão isolada, o Brasil da casa é não somente razoável, mas insubstituível. É o Brasil que produz saudade e do qual não queremos jamais sair. Já o da rua, com seus índices e suas parafernálias quantitativas, é um Brasil que foi destinado a dar errado e a cair no tal abismo.

Hoje, felizmente, estamos vendo melhor essas dimensões, num mundo que possivelmente dá mais razão a nós, nascidos mais como mulatos culturais do que como aqueles arianos que, em nome da homogeneidade, produziram as grandes tragédias da humanidade.

Jardim Ubá, 25 de julho de 2012.

Referências Bibliográficas

BaKHtin, Mikhail. (1987), A cultura popular na Idade Média e no Renascimento. São Paulo, Hucitec.

DAMATTA, Roberto. (1976), Um mundo dividido: a estrutura social dos indios Apinayé. Petrópolis, Vozes.

(1979), Carnavais, malandros e heróis: para uma sociologia do dilema brasileiro.

Rio de Janeiro, Zahar. . (1981), Relativizando: uma introdução à antropologia social. Petrópolis, Vozes. (1985), A casa \& a rua: espaço, cidadania, mulher e morte no Brasil. São Paulo, Brasiliense.

(1993), Conta de mentiroso: sete ensaios de antropologia brasileira. Rio de Janeiro, Rocco.

Dumont, Louis. (1968), "Préface". In: Evans-Pritchard, E. E. Les Nuer. Paris, Gallimard, pp. 1-15. 
DuRKHeIm, Émile. ([1912] 1996), As formas elementares da vida religiosa. São Paulo, Martins Fontes.

SCHOPENHAUER, Arthur. ([1819] 2005), O mundo como vontade e como representação. São Paulo, Editora da Unesp.

\section{Resumo}

Recordações de como me deparei com e tentei compreender o espaço por meio de uma sociologia

Neste trabalho eu avalio as implicaçóes teóricas do conceito de espaço a partir de uma experiência na etnologia e de estudos de interpretação do Brasil do ângulo das celebrações e dos costumes rotineiros.

Palavras-chave: Espaço (categoria social); Sociologia francesa (Émile Durkheim); Brasil (sociedade); Ritual (nação); Cultura (valores).

\section{Abstract}

Recollections of how I encountered and tried to comprehend space by means of a definite sociology

In this paper I evaluate the theoretical implications of the concept of space based on my own experience in ethnology and on studies which interpret Brazil from the viewpoint of celebrations and routine customs.

Keywords: Space (social category); French sociology (Émile Durkheim); Brazil (society); Ritual (nation); Culture (values). 